\title{
IMPACT OF UV-C IRRADIATION OF POTATO SEED TUBERS ON THE DEFECTS IN POTATO PLANT CROPS
}

\author{
Tomasz Jakubowski*
}

Department of Machinery Management, Ergonomics and Production Processes, University of Agriculture in Krakow, Poland; ORCID 0000-0002-5141-2705

*Corresponding author: e-mail: Tomasz.Jakubowski@urk.edu.pl

\begin{tabular}{|c|c|}
\hline ARTICLE INFO & ABSTRACT \\
\hline $\begin{array}{l}\text { Article history: } \\
\text { Received: August } 2019 \\
\text { Received in the revised form: } \\
\text { September } 2019 \\
\text { Accepted: September } 2019 \\
\end{array}$ & $\begin{array}{l}\text { The purpose of the paper was to determine the impact of UV-C irradia- } \\
\text { tion of seed potatoes on the formation of tuber defects in the progeny } \\
\text { crop. The field experiment was carried out in } 2016-2018 \text {, and the object } \\
\text { of research was potato plants of the Vineta, Lord and Owacja varieties. } \\
\text { Different heights of the UV-C radiator above the chamber bottom (40- }\end{array}$ \\
\hline $\begin{array}{l}\text { Keywords: } \\
\text { potato, } \\
\text { tuber, } \\
\text { ultraviolet } C, \\
\text { defect }\end{array}$ & $\begin{array}{l}100 \mathrm{~cm}) \text { and exposure times }(1-30 \mathrm{~min} \text {.) were used. Data was analyzed } \\
\text { with the STATISTICA } 13.3 \text { program, at the assumed significance level } \\
\alpha=0.05 \text {, using a non-parametric test } \chi^{2} \text { for multidimensional contin- } \\
\text { gency tables. In the scope of the parameters of the chamber for UV ir- } \\
\text { radiation of plant material adopted in the experiment, no statistically } \\
\text { significant UV-C effect on potato tuber defects was demonstrated. In } \\
\text { the potato tuber crop of the examined varieties, shape deformations in } \\
\text { the form of kidney and spindle disease were identified. The crop of po- } \\
\text { tato obtained from seed potatoes irradiated with UV-C demonstrated } \\
\text { a lower percentage of deformed tubers, as compared to the control com- } \\
\text { bination. }\end{array}$ \\
\hline
\end{tabular}

\section{Introduction}

Both the consumer, and the processing industry demand potato tubers with an appropriate shape and weight. Tuber deformations are defects that affect the quality of the crop intended for sale, and may reduce the farmer's profit from potato farming (Nowacki, 2015; 2016; Mozolewski et al., 2014; Zgórska, 2013, Lopes et al., 2013). The reasons for the formation of defects in potato tubers are mainly pathological changes occurring during the growing season and storage. Defects can also be generated by pests, mainly grubs (a type of oligopodial larvae of the Scarabaeidae or Lucanidae beetle families) and wireworms (Elateridae). In addition to tuber defects caused by diseases and pests, the crop may also contain tubers with defects, which were caused by abiotic factors. These are physiological defects, manifested both in the external appearance of the tuber and in the condition of its flesh (Jankowska and Lutomirska, 2014). Such defects arise usually as a result of improperly used agricultural technology, as well as adverse soil or climatic conditions during the growing season. Soil and climate factors can cause deformation, greening and cracking of tubers, depaupered crop, as 
Tomasz Jakubowski

well as rust spots and the hollowness of the pulp (Hara-Skrzypiec, 2013; Erlichowski, 2010; Nowacki, 2006; Cupiał and Kowalczyk, 2018). Deformations and developmental defects of tubers may take the form of: secondary tubers, kidney disease (narrowing in the central part of the tuber), spindle disease (conical end of the heel end), multidirectional deformations (defined as clear deviations from the typical shape of the variety) and peridermal and parenchymal fractures (the fracture tissue scars with time, forming a cork layer) (Jankowska and Lutomirska, 2014). Peripheral greening is also an external defect, resulting from the accumulation of chlorophyll in the skin (when colorless amyloplasts transform into chloroplasts, and the photosynthetic apparatus is formed) (Helle et al., 2018). The most common internal defects in potato tubers are the so called hollow heart (a hole formed in the central part of the tuber, surrounded by brown tissue, which is the result of a very rapid tissue growth) and black heart (the effect of insufficient oxygenation of tubers). As a result of the plant's water management disorder during the growing season, or too high temperature during the period of harvesting and transport, potato may also have dark spots inside the tuber flesh (HaraSkrzypiec, 2013). The cause of the tuber defects and deformations described above are abiotic factors affecting the potato plant. The author's work (Jakubowski, 2009) describes the positive effect of microwave radiation, measured by the yielding effect, on potato plants subjected to simulated drought stress. Currently, research is underway on the possibility of using UV-C wavelength as a physical method to protect potato crop (seed potatoes, as well as tubers intended for consumption and processing) during its long-term storage (Sobol et al., 2018). The application of UV-C radiation to stored seed potatoes requires research on the consequences of this physical method on the progeny plants.

The purpose of the paper was to determine the impact of UV-C irradiation of seed potatoes on the formation of tuber defects in the progeny crop.

\section{Material and methods}

The field experiment was carried out in 2016-2018. The object of research was potato plants (Solanum tuberosum L.), varieties Vineta, Lord and Owacja. Qualified seed potatoes were placed at the bottom of the chamber (Jakubowski and Wrona, 2012) and irradiated with UV-C using a proprietary research stand (Fig. 1). 


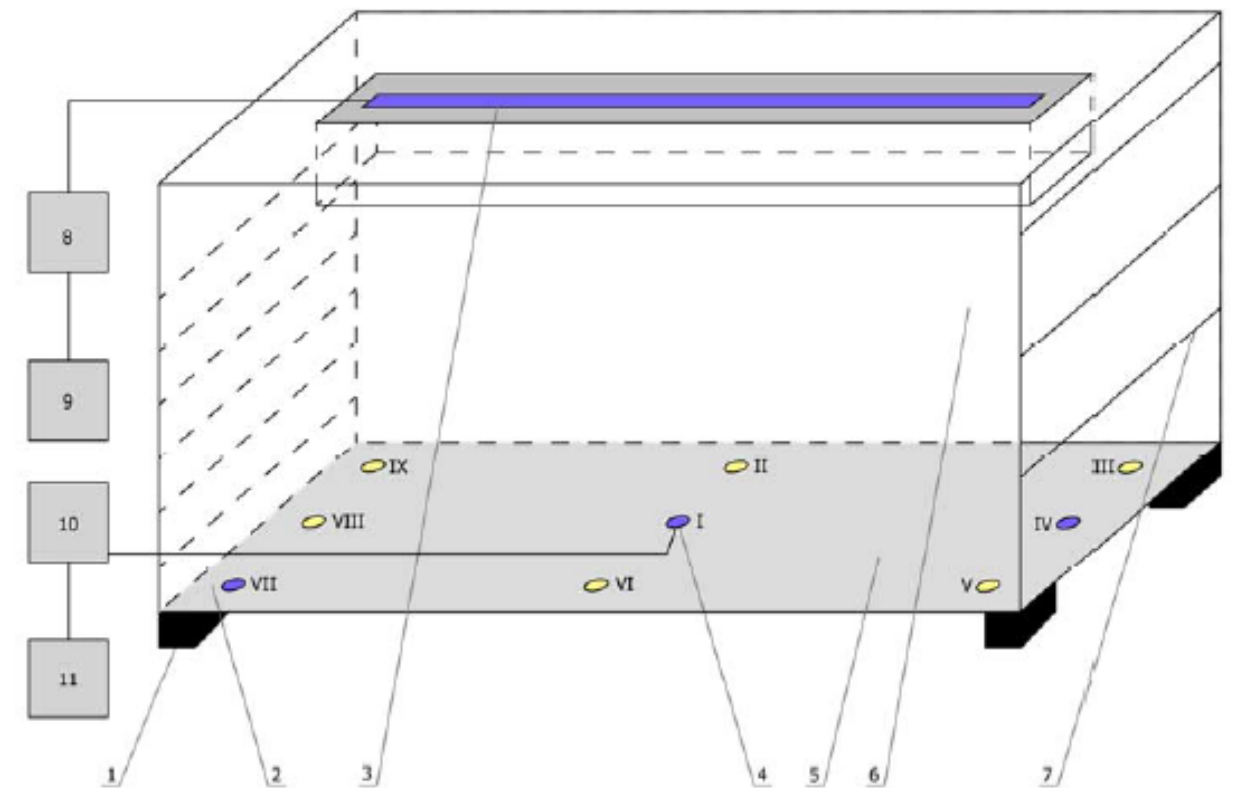

Source: Jakubowski and Wrona, 2012

Figure 1. The stand for irradiation of potato tubers with $U V$-C light: 1 -supports, 2 -bottom of the chamber, $3-U V$-C radiator, 4 - location of the UV-C sensor (I-IX), 5 -location of potato tubers, 6 - interior of the chamber, $7-U V$-C radiator height adjustment, 8 -timer, 9 - power source, $10-U V$-C radiation meter, 11 - computer (for aggregating the research data)

Three heights of the UV-C radiator above the bottom of the chamber were used $(40,70$ and $100 \mathrm{~cm}$ ) and three exposure times (1, 10 and $30 \mathrm{~min}$.). The experiment included a control sample. The operating parameters of the UV-C chamber were determined arbitrarily. A single combination included 90 seed potatoes and 3 replications. The plot experiment was carried out in a completely randomized system. Seed potatoes were placed in the soil immediately after exposure. In all years of the experiment, the same system of agrotechnical treatments was used, as provided for the proper cultivation of potato plants. The harvest was carried out annually, in late August. In the crop, subsequent tuber defects were assessed on the basis of organoleptic examination of the occurrence and type of deformities (secondary tubers, kidney disease, spindle disease and multidirectional deformations), greening, cracks and internal defects (hollowness and blotchiness of the heart). The evaluation was made in the 0-1 system ( 0 - not defective, 1 - defective). In the event of a defect, its type was determined using the same system (0-1). Internal defects were sought by cutting the tuber along its main axis. The UV-C dose absorbed by the seed potato was determined by a meter (MIER-UV-C 254, with an accuracy of $+/-2 \%$ ) equipped with a photodiode probe (LP UV-C 01) with sensitivity of $0.19 \mu \mathrm{W} \cdot \mathrm{cm}^{-2}$ and sampling time of $0.4 \mathrm{~s}$. The meter was paired with the computer archiving 
measurement data via RS-232 serial interface. A detailed description of the methodology of irradiation of plant material in the UV-C chamber is found in the author's works (Jakubowski and Pytlowski, 2013; 2014). Data analysis was performed in the STATISTICA 13.3 program at the assumed significance level of $\alpha=0.05$. Due to the dichotomous nature of the dependent variables (the nominal scale), the non-parametric test $\chi^{2}$ was used in multidimensional contingency tables. The following research hypotheses were formulated:

$H_{0}-O_{i j} \ldots=E_{i j}$ for all categories (no UV-C impact on potato tuber defects was identified), $H_{l}-O_{i j} \ldots \neq E_{i j}$ for all categories (impact of UV-C on potato tuber defects was identified), where:

$O_{i j}$ and $E_{i j}$ are the frequencies observed in the contingency table, and the corresponding expected frequencies.

\section{Results and discussion}

The value of UV-C radiation that reached the seed potatoes at the bottom of the chamber depended on the height of the radiator and was $69.4,86.3$ and $171.9\left(\mu \mathrm{W} \cdot \mathrm{cm}^{-2}\right)$ at respective radiator heights of 100, 70 and $40 \mathrm{~cm}$ above the bottom of the chamber. The dose of UV-C absorbed by the seed potato depended both on the height of the radiator above the bottom of the chamber, and on the time of exposure (the product of radiation values and exposure times adopted in the experiment) and was in the range of $4164-309420 \mu \mathrm{W} \cdot \mathrm{s} \cdot \mathrm{cm}^{-2}$.

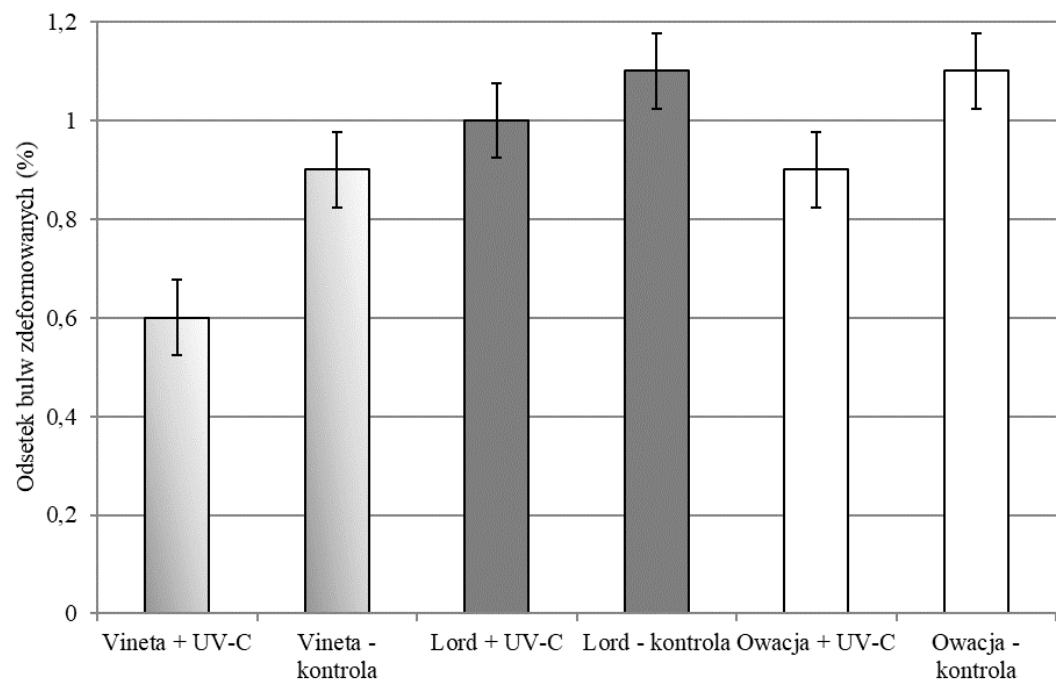

Figure 2. Percentage of potato tubers with a defect in the form of shape deformation (vertical bars on the graph illustrate the standard error) 
Impact of UV-C irradiation of potato seed tubers...

No statistically significant differences were found in any of the tested combinations of the experiment in relation to the control sample (statistic value $\chi^{2}$ was insignificant at the adopted level of test probability). No significant differences were found between the individual combinations of experience. There were therefore no grounds for rejecting $\mathrm{H}_{0}$. The only defects found in the potato tuber crop of the studied variations are shape deformations in the form of kidney or spindle disease (Fig. 2 and 3). The crop of potato obtained from seed potatoes irradiated with UV-C demonstrated a lower percentage of deformed tubers, as compared to the control combination (Fig. 2) The obtained results indicate that the applied physical method can prevent the process of forming defects in potato tubers. However, it is advisable to carry out further experiments, taking into account different UV-C exposure times and other potato varieties.

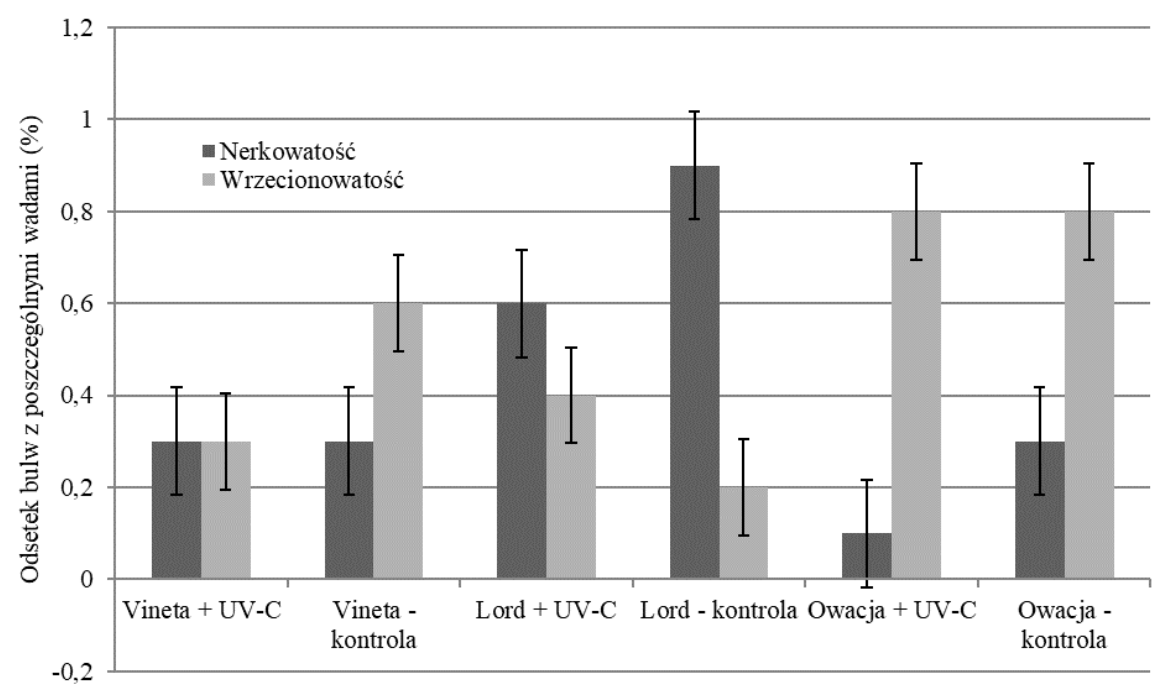

Figure 3. Percentage of potato tubers with a defect in the form of kidney or spindle deformation (vertical bars on the graph illustrate the standard error)

\section{Conclusions}

1. In the scope of the parameters of the chamber for UV irradiation of plant material adopted in the experiment, no statistically significant UV-C effect on potato tuber defects was demonstrated.

2. In the potato tuber crop of the examined varieties, shape deformations in the form of kidney and spindle disease were identified.

3. The crop of potato obtained from seed potatoes irradiated with UV-C demonstrated a lower percentage of deformed tubers, as compared to the control combination. 
Tomasz Jakubowski

\section{References}

Cupiał, M., Kowalczyk, Z. (2018). Computer-aided fertilisation using the Nawozy-5 (Fertiliser-5) software. Contemporary Research Trends in Agricultural Engineering BIO Web Conf., 10(2018) 02002. https://doi.org/10.1051/bioconf/20181002002.

Hara-Skrzypiec, A. (2013). Wady i uszkodzenia bulw ziemniaka wywołane różnymi czynnikami. Ziemniak Polski, No. 4, 30-35.

Helle, S., Bray, F., Verbeke, J., Devassine, S., Courseauxm, A., Facon, M., Tokarski, C., Rolando, C., Szydlowski, N. (2018). Proteome Analysis of Potato Starch Reveals the Presence of New Starch Metabolic Proteins as Well as Multiple Protease Inhibitors. Front Plant Sci. 9, 746.

Erlichowski, T. (2010). Podatność różnych odmian ziemniaka na uszkodzenia bulw powodowane przez drutowce (Elateridae) i wykorzystanie tego zjawiska w uprawie ekologicznej i integrowanej. Prog. Plant Prot. 50(3), 1230-1235.

Jankowska, J., Lutomirska, B. (2014). Czynniki środowiska determinujące występowanie spękań i deformacji bulw ziemniaka. Ziemniak Polski, No. 4, 18-24.

Jakubowski, T. (2009). Reakcja roślin ziemniaka napromieniowanych mikrofalami na symulowany stres suszy. Inżynieria Rolnicza, 8(117),15-22.

Jakubowski, T., Wrona, P. (2012). Effectiveness of UVC radiation influence on the development of tuber potato tuber crops. Part I - test stand. Acta Scientiarum Polonorum - Technica Agraria, No 11(1-2), 33-41.

Jakubowski, T., Pytlowski, T. (2013). Influence of ultraviolet radiation on the growth, development and yielding of potato plants (preliminary studies). Agricultural Engineering. No. 3(145), 99-107.

Jakubowski, T., Pytlowski, T. (2015). Influence of UV-C radiation on the degree of infection of stored potato tubers by Rhizoctonia Solani Kühn. Agricultural Engineering, 2(154), 35-43.

Lopes, E., Jadoski, S., Saitos, L., Ramos, M. (2013). Plant morphological characteristics and yield of potato cv. Ágata in function to fungicides application. Braz. J. Appl. Technol. Agric. Sci. 6(1), $37-46$.

Mozolewski, W., Radzymińska, M., Łazicki, T. (2014). Jakość ziemniaka spożywczego w opinii konsumentów. Biuletyn IHAR, 272, 5-16.

Nowacki, W. (2006). Straty plonu handlowego ziemniaków powodowane przez choroby i szkodniki w 2005 roku. Prog. Plant Prot, 46(1), 193-201.

Nowacki, W. (2015). Szanse i zagrożenia rynku ziemniaka w Polsce. Roczniki Naukowe Stowarzyszenia Ekonomistów Rolnictwa i Agrobiznesu, 17(1), 169-175.

Nowacki, W. (2016). Rynek ziemniaków jadalnych w Polsce - stan obecny i perspektyw rozwoju. Roczniki Naukowe Stowarzyszenia Ekonomistów Rolnictwa i Agrobiznesu, 18(1), 196-201.

Sobol, Z., Jakubowski, T., Wrona, P. (2018). The effect of UV-C stimulation of potato tubers and soaking of potato strips in water on density differences of intermediates for French-fry production. BIO Web of Conferences 10, 02031 (2018) https://doi.org/10.1051/bioconf/20181002031 Contemporary Research Trends in Agricultural Engineering, 1-5.

Zgórska, K. (2013). Wykorzystanie ziemniaka do celów spożywczych i przemysłowych. Inżynieria Przetwórstwa Spożywczego, 3(7), 5-9. 


\section{WPLYW NAŚWIETLANIA SADZENIAKÓW ZIEMNIAKA UV-C NA POWSTAWANIE WAD BULW W PLONIE ROŚLIN POTOMNYCH}

Streszczenie. Praca miała na celu określenie wpływ naświetlania sadzeniaków ziemniaka UV-C na powstawanie wad bulw w plonie roślin potomnych. Ścisłe doświadczenie polowe realizowano w latach 2016-2018 a obiektem badań były rośliny ziemniaka odmiany Vineta, Lord i Owacja. Stosowano różne wysokości promiennika UV-C nad dnem komory $(40,70$ i $100 \mathrm{~cm})$ oraz czasy naświetlania $(1,10$ i 30 min.). Analizę danych wykonano w programie STATISTICA 13.3 na założonym poziomie istotności $\alpha=0,05$ stosując nieparametryczny test $\chi^{2}$ dla wielowymiarowych tabel kontyngencji. W zakresie przyjętych w doświadczeniu parametrów pracy komory do naświetlania materiału roślinnego ultrafioletem nie wykazano statystycznie istotnego wpływu UV-C na powstawanie wad bulw ziemniaka. Stwierdzono, że w plonie bulw ziemniaka badanych odmian występują deformacje kształtu mające postać nerkowatości i wrzecionowatości. W plonie ziemniaka, uzyskanego z roślin sadzeniaków naświetlanych UV-C, stwierdzono mniejszy odsetek bulw zdeformowanych w odniesieniu do kombinacji kontrolnej.

Słowa kluczowe: ziemniak, bulwa, ultrafiolet w paśmie $\mathrm{C}$, wada 